\title{
Марина Родина
}

$$
|\mathbf{C}| \mathbf{O}|\mathbf{P}| \mathbf{E} \mid \underset{\substack{\text { Member since } \\ \text { JM14477 }}}{|\mathbf{E}| 9}
$$

(iD https://orcid.org/0000-0002-6664-2458

Белорусский государственный университет

Институт дополнительного образования

Кафедра русского языка как иностранного в профессиональном обучении

220030, Минск, пл. Независимости 4

mararoenator@gmail.com

\section{Анна Падо, Беседа \\ Учебный комплекс для изучения русского языка \\ Издательство: Draco, сc. 130}

\author{
Anna Pado, Беседa \\ Russian Language Course \\ Publisher: Draco, pp. 130
}

\begin{abstract}
Резюме
В настоящей статье представлена рецензия на учебный комплекс по русскому языку как иностранному на начальном уровне - Беседа (автор - Анна Падо). В частности, рассматриваются основные принципы построения учебного комплекса (коммуникативность, проблемность, модульность) и концепции, отраженные в его содержании. Представленный учебный комплекс предназначен для поляков и является этноориентированным. В учебном комплексе присутствуют языковые и речевые упражнения, учебные и аутентичные тексты, богатый грамматический и лексический материал, иллюстрации.
\end{abstract}

Ключевые слова: Беседа, учебный комплекс, языковые и речевые задания, материал.

\section{Summary}

The article reviews an educational complex of Russian as a foreign language for beginners, Беседа (author: Anna Pado). In particular, the basic principles of building an educational complex (communicativeness, problematicity, modularity) and its embedded concepts are considered. The discussed educational complex is intended for Poles and is ethno-oriented. It contains language and speech exercises, educational and authentic texts, rich grammatical and lexical material, as well as images.

Keywords: Беседa, training complex, language and speech assignments, material. 
Постоянно изменяющиеся требования к образовательной среде, содержанию обучения и учебным технологиям делают актуальной проблему создания учебного комплекса по иностранному языку. Дискуссии о том, каким критериям должен соответствовать учебный комплекс, постоянно ведутся в методической науке. При этом большинство исследователей сходятся во мнении, что современный учебник должен быть основан на принципах коммуникативности, проблемности, модульности, системности, преемственности и наглядности.

Тем более радует, что рассматриваемый учебный комплекс Беседа (автор - Анна Падо), предназначенный для начинающих (уровни A1/B1), как раз учитывает эти принципы и представляет собой удачный образец воплощения коммуникативной методики в учебном пособии в соответствии с запросами современного образовательного пространства.

Начнем обзор учебника Беседа с определения его основных характеристик. Учебный комплекс является этноориентированным, поскольку предназначен для поляков, изучающих русский язык. При его создании учитывался фактор близкородственности польского и русского языков. Именно это позволило автору на самых ранних этапах работы с учебником вводить разнообразные задания, выполнение которых на слух и письменно основано на сходстве славянских языков и использовании позитивного переноса навыков и умений из родного языка в иностранный. Учебник предназначен для изучения русского языка вне языковой среды, поэтому реализует задачу создания искусственной языковой среды, максимально приближенной к аутентичной.

Следующим определяющим фактором для автора учебного комплекса становится коммуникативность. Современная образовательная парадигма определяет межкультурное общение основной целью изучения иностранного языка, а коммуникативная методика помогает научить иноязычному общению. Для обучения общению в Беседе присутствуют коммуникативные речевые задания социокультурного и культуроведческого характера. Следует отметить разнообразие изучаемых тем, насыщенность заданий и текстов информацией о культуре России (география, традиции, праздники, фразеология и др.) и о мировой культуре. Непринужденная и интересная Беседа помогает учащимся осваивать русскую речь и расширять свой культурный кругозор. Ситуативно-тематическое представление языкового материала и практически ориентированное обучение также обеспечивают коммуникативную направленность учебного комплекса. Аутентичные материалы (тексты, песни, стихи) определяют культурологическую ценность пособия.

Кроме обучения речевому общению, целью учебного комплекса является формирование грамматических и лексических навыков. Русский язык, как и польский, это язык синтетического типа, который имеет разветвленную систему грамматических значений и разные способы их выражения. Овла- 
дение грамматическими правилами необходимо для грамотного использования русского языка в различных ситуациях. Учебник снабжен большим количеством ярких и хорошо структурированных грамматических таблиц и комментариев. В учебной тетради представлены речевые коммуникативные и языковые задания.

Нужно отметить ориентированность Беседы на сформированность у учащихся навыков владения информационными технологиями. Работа c CD, использование гаджетов для поиска и обработки информации в Интернете разнообразят учебный процесс и облегчают усвоение нового материала.

Следует выделить направленность учебного комплекса на индивидуализацию обучения. Для этого учащему предоставлен выбор формы и сложности задания и темы высказывания, а также роли в групповом выполнении заданий.

Следующей характерной чертой учебного комплекса является его наглядность, яркое и запоминающееся оформление. Это и разноцветные, четкие грамматические таблицы, диаграммы, оригинальные фотографии, коллажи, остроумные рисунки, карикатуры, выделение шрифтом и цветом. Хотелось бы отметить удачный и плодотворный творческий тандем автора Анны Падо и художника Анны Теодорчик в оформлении. Наглядность особенно важна для современной молодежи, ориентированной на визуализацию информации, которая значительно облегчает восприятие и усвоение учебного материала.

Обратимся к структуре и содержанию учебного комплекса Беседа. В состав каждого пакета (части $1,2,3$ ) входят учебник, рабочая тетрадь, CD (a также kod QR), книга для учителя. Обучение видам речевой деятельности - чтению, говорению, аудированию и письму происходит взаимосвязанно, осуществляется перенос навыков из одной активности в другую в рамках русского языка, а также из родного языка в иностранный. Структура учебника носит модульный характер. Учебный комплекс рассчитан на трехлетнее или четырехлетнее обучение в зависимости от назначенной учителем и учениками цели организации дидактического процесса.

Первая часть учебника, предназначенная для изучения русского языка на начальном уровне, включает следующие разделы:

Мне все понятно (актуализация культуроведческих знаний о России, о коммуникативной культуре русских путем выполнения аудитивных заданий);

Пишу и читаю (усвоение русского алфавита, формирование графических и лексико-грамматических навыков и развитие умений чтения и письма взаимосвязанно с аудированием (диктанты), актуализация знаний о славянах и славянских языках, совершенствование произношения и развитие умений говорения); 
Я уже общаюсь (взаимосвязанное обучение видам речевой деятельности с упором на говорение, коммуникативные задания, базовые темы Знакомство, Семья, Учеба, Город, Жилье).

Кроме этого, учебник содержит разделы Повторяем и закрепляем (совершенствование лексических и комуникативных навыков); Хочу знать больше (культуроведческие тексты и коммуникативные задания, а также проекты); Формуль общения (коммуникативная культура); Учимся учить язык (методические рекомендации для учащихся на родном языке); Грамматические таблииы и Тематический словарь. К учебнику прилагается учебная тетрадь с разнообразными заданиями.

Вторая часть учебника Беседа предназначена для продолжающих изучать русский язык и имеет еще более ярко выраженную коммуникативную и культуроведческую направленность. В учебнике освещаются социокультурные темы Культура, Услуги и СМИ, Кулинария, Праздники и гости. Занимательные коммуникативные задания и тексты о современной культуре вводят учащихся в речевое инокультурное общение. Кроме этого, традиционно представлены интересные тексты для чтения, Формулы общения и Грамматические таблицы. В учебной тетради даны задания по темам учебника, направленные на совершенствование лексико-грамматических навыков и развитие умений во всех видах речевой деятельности.

Заключительная, третья часть учебного комплекса также включает в себя учебник, $\mathrm{CD}$ и учебную тетрадь. Представлены темы Здоровый образ жизни, Труд и профессия, Мир вокруг нас, Путешествие. Лексический запас учащихся значительно расширяется. Проводится работа не только над навыками и умениями, но и пониманием текстов (работа со стратегиями понимания, обучение просмотровому чтению и краткому изложению).

В заключении мы можем констатировать, что появление в Польше нового учебного комплекса, последовательно реализующего принципы коммуникативности и культуроведческой направленности, весьма полезно для изучающих русский язык. Беседа содержит тексты и задания, вызывающие живой интерес учащихся и оптимизирующие работу преподавателя. Учебный комплекс Беседа не только формирует основные языковые компетенции, но и непосредственно готовит учащихся к межкультурному общению и диалогу культур. 